\begin{tabular}{|l|l|l||}
\hline \multicolumn{2}{|c|}{ PublisherInfo } \\
\hline \hline PublisherName & $:$ & BioMed Central \\
\hline \hline PublisherLocation & $:$ & London \\
\hline \hline PublisherImprintName & $:$ & BioMed Central \\
\hline \hline
\end{tabular}

\title{
Wild olives
}

\begin{tabular}{|l|l|l||}
\hline \multicolumn{2}{|c|}{ ArticleInfo } \\
\hline \hline ArticleID & $:$ & 4229 \\
\hline \hline ArticleDOI & $:$ & $10.1186 /$ gb-spotlight-20011018-01 \\
\hline \hline ArticleCitationID & $:$ & spotlight-20011018-01 \\
\hline \hline ArticleSequenceNumber & $:$ & 300 \\
\hline \hline ArticleCategory & $:$ & Research news \\
\hline ArticleFirstPage & $:$ & 1 \\
\hline \hline ArticleLastPage & $:$ & 2 \\
\hline \hline & & RegistrationDate : 2001-10-18 \\
ArticleHistory & $:$ & OnlineDate $\quad$ 2001-10-18 \\
\hline \hline ArticleCopyright & $:$ & BioMed Central Ltd2001 \\
\hline \hline ArticleGrants & $:$ & \\
\hline \hline ArticleContext & $:$ & 130592211 \\
\hline \hline
\end{tabular}




\section{Jonathan B Weitzman}

Email: jonathanweitzman@hotmail.com

Domestication and cultivation have resulted in the generation of wild-looking forms of Mediterranean fruit crops derived from cultivated plants (cultivars). In the October 18 Nature, Lumaret and Ouazzani describe a genetic hunt for genuinely wild olives in forests of the Mediterranean (Nature 2001, 413:700). They collected samples from ten forests (40 trees per forest) in seven countries around the Mediterranean basin, scored them for allozyme markers, and compared them with the same loci from 802 domsticated olive clones. In the forest samples they found alleles associated with characteristics unsuitable for domestication. Lumaret and Ouazzani conclude that ancient wild olive stocks persist today within the western part of the Mediterranean basin.

\section{References}

1. Nature, [http://www.nature.com]

2. The Olive Research Group, [http://www.waite.adelaide.edu.au/HVO/groups/olives/olives.htm] 